ARTICLE

\title{
Larval fish assemblages from channels and fjords of south Pacific Patagonia: effects of environmental conditions
}

\author{
Ensambles de larvas de peces de canales y fiordos de la Patagonia del \\ Pacífico Sur: efectos de las condiciones ambientales

\section{Gissella Castillo-Hidalgo ${ }^{1}$, Mauricio F. Landaeta ${ }^{1, *}$, Eduardo Anaya-Godínez ${ }^{2}$ and Claudia A. Bustos ${ }^{1}$}

\begin{abstract}
${ }^{1}$ Laboratorio de Ictioplancton (LABITI), Facultad de Ciencias del Mar y de Recursos Naturales, Universidad de Valparaíso, Av. Borgoño 16344, Viña del Mar, Chile. *mauricio.landaeta@uv.cl

${ }^{2}$ Programa de Maestría en Ciencias de Manejo de Recursos Marinos, Centro Interdisciplinario de Ciencias Marinas, Instituto Politécnico Nacional, Av. IPN s/n, Col. Playa Palo de Santa Rita, C.P. 23096, La Paz, Baja California Sur, México

Resumen.- Los fiordos de la Patagonia chilena, se caracterizan por fuertes gradientes físico-químicos horizontales y verticales que ejercen consecuencias en la distribución y abundancia del ictioplancton. Se recolectaron muestras de plancton mediante arrastre oblicuo con una red bongo en 40 estaciones, a bordo de un crucero bio-oceanográfico en fiordos interiores de la XI región sur de Chile $\left(47^{\circ}\right.$ a $\left.51^{\circ} \mathrm{S}\right)$. Los datos ambientales de la columna de agua fueron obtenidos mediante un perfilador de conductividad-temperatura-profundidad (CTD), y la turbidez fue medida con un turbidímetro portátil entre 0 y $100 \mathrm{~m}$ de profundidad. Las estaciones se distribuyeron por zona oceánica, canales y área de influencia de agua dulce. Se recolectó un total de 1424 larvas, representando 21 familias y 41 taxa. Los taxa dominantes fueron Maurolicus parvipinnis (31\%), Sebastes oculatus (12\%), Merluccius australis (11\%), Lampanyctodes hectoris (10\%) y Bathylagichthys parini (8\%). La mayor variabilidad ambiental fue dada por la salinidad, principalmente en la zona con descarga de agua dulce. La zona oceánica presento una columna de agua mezclada con la mayor presencia de mictófidos como L. hectoris y peces hacha M. parvipinnis. No hubo un efecto significativo de los gradientes de turbidez sobre los ensambles de larvas de peces durante primavera. La zona de los canales se aprecia una mayor estratificación de la salinidad, densidad y una disminución de la turbidez, donde se distribuyeron en general las especies con menores abundancias. Por lo tanto, es posible definir dos ensambles ictioplanctónicos, uno con influencia oceánica y el otro de canales y zonas interiores.
\end{abstract}

Palabras clave: Ictioplancton, turbidez, gradiente salino

\begin{abstract}
Chilean Patagonian fjords are characterized by strong stratification and chemical gradients which influence the ichthyoplankton distribution and abundance. Plankton samples were collected through bongo net oblique tows in 40 stations from onboard a bio-oceanographic cruise took place in inner fjords of southern Chile $\left(47^{\circ}\right.$ to $\left.51^{\circ} \mathrm{S}\right)$. Water column physical data were obtained with a conductivity-temperature-depth profiler (CTD) and turbidity was measured with a portable turbidimeter from 0 to $100 \mathrm{~m}$ depth. Stations were distributed by three zones: oceanic, channels and continental waters. A total of 1424 larvae were collected, representing 21 families. Dominant taxa were Maurolicus parvipinnis (31\%), Sebastes oculatus (12\%), Merluccius australis (11\%), Lampanyctodes hectoris (10\%), and Bathylagichthys parini (8\%). Most of the environmental variability was determined by salinity, mainly in the area where continental waters are discharged. The water column in the oceanic zone presented mixed waters dominated by the myctophid L. hectoris and the sternoptychid $M$. parvipinnis. No significant effect of turbidity gradients on larval fish assemblages was evident during spring. The channel zone was both more saline, and density stratified with less turbidity, and lower abundance of species. Two ichthyoplanktonic assemblages were evident, one living in oceanic waters, and the other from channels and inner zones.
\end{abstract}

Key words: Icthyoplankton, turbidity, salinity gradients

\section{INTRODUCTION}

The strong physical gradients found in the water column of coastal Patagonian seas may exert important biological consequences in the distribution and abundance of zooplankton and ichthyoplankton. Horizontal, vertical and chemical stratification is found in the fjord habitats of southern Chile. The estuarine and benthic ecology of benthic populations is shaped by seasonal physical disturbances of natural origin that are associated with river discharge resulting from melting ice and the release of suspended particulate material (Vargas et al. 2011, Quiroga et al. 2012, Landaeta et al. 2013, Zenteno et al. 2014). 
The extensive Baker/Martínez fjord complex is situated between the Northern and Southern Ice Fields in south Patagonia. The two largest Patagonian rivers, Baker and Pascua, can discharge up to 1400 and $1000 \mathrm{~m}^{3}$ $\mathrm{s}^{-1}$ during a typical spring-summer day (Meerhoff et al. 2013). Recent studies have documented the seasonal variability of the hydrography (Aiken 2012, Meerhoff et al. 2013), the meroplankton community structure (Meerhoff et al. 2014, 2015) and the variability on growth and feeding of marine fish larvae (Landaeta et al. 2012).

The Chilean Patagonia is utilized both as spawning grounds and nursery areas for small pelagic fishes (sardines, anchovies, Bustos et al. 2008a), demersal fishes (hakes, Bustos et al. 2015), and mesopelagic fishes (sternoptychids, myctophids, Landaeta et al. 2011a, b). Recent evidence indicates that vertical stratification plays a role in the increase of predator-prey interactions in northern Patagonia (Bustos et al. 2008b, 2011; Landaeta et al. 2011b), and the negative effect of freshwater input in the inner sea and turbulence in exposed areas for larval fish condition (Zenteno et al. 2014). However, the role of turbidity in the spatial structure of early life stages of marine fishes in south Patagonia remains unknown.

Water turbidity is influenced by freshwater runoff, with rainfall flushing organic matter, soil and sand particles into rivers, lakes and coastal seas. The increase in organic matter increases eutrophication that encourages algal blooms, which lead to further increases in turbidity (Utne-Palm 2002). Turbidity may play a role in the trophic interactions of predators and prey in estuarine environments (Boehlert \& Morgan 1985, Grecay \& Targett 1996). The positive effect of turbidity on prey contrast depends on the optical properties, scattering properties of suspended particles and the visual sensitivity of the predator (Utne-Palm 2002).

The objective of this research was to describe relationships among oceanographic conditions and ichthyoplankton assemblages during austral Spring 2014, in an area that is largely influenced by the turbid freshwater input in the channels of South Patagonia. Therefore, the role of turbidity in the structure of larval fish assemblages in Chilean Patagonia was tested.

\section{MATERIALS AND METHODS}

\section{FIELD SAMPLING AND LABORATORY WORK}

Between 10 and 22 October 2014, bio-oceanographic sampling was carried out along the Patagonian fjords, Southeastern Pacific Ocean (Fig. 1). Plankton samples were collected from 40 stations. At each station, CTD profiles of environmental data (temperature, salinity, density) were collected from the surface at $1000 \mathrm{~m}$ depth or $10 \mathrm{~m}$ above the bottom with a Seabird SBE-19 CTD profiler. Turbidity was measured (Hach ${ }^{\circledR} 2100 q$ portable turbidimeter) on water at $0,10,30,50$ and $100 \mathrm{~m}$ depth. Plankton samples were collected from $100 \mathrm{~m}$ depth or 10 $\mathrm{m}$ above the bottom to the surface through oblique tows with a Bongo net (60 $\mathrm{cm}$ diameter, $300 \mu \mathrm{m}$ mesh) with a TSK flowmeter mounted in the frame of the net to estimate the volume of the seawater filtered. Towing speed was approximately 2 knots. The volume filtered in each tow was calculated from flowmeter counts. Once over the vessel, the nets were washed and all samples were fixed in 5\% formalin buffered with sodium borate. Once in the laboratory, plankton samples were rinsed and preserved in $96 \%$ ethanol.

Fish larvae were identified to the lowest possible taxonomic level using relevant taxonomic keys (Moser 1996, Neira et al. 1998, Balbontín et al. 2004 and Landaeta et al. 2008). Larval abundance was standardised to number of larvae per $1000 \mathrm{~m}^{-3}$.

\section{Data ANalyses}

Oceanographic stations were categorized into 4 locations: Golfo de Penas (GP), Baker Channel (BC), Messier-Wide Channels (MWC) and Fallos-LadrillerosPicton Channels (FLPC) (Fig. 1). Principal component analysis (PCA) was carried out for the following oceanographic variables: sea surface temperature (SST, ${ }^{\circ} \mathrm{C}$ ), Sea Surface Salinity (SSS), Sea Surface Density (SSD, sigma-t), maximum turbidity (MaxTurb, NTU), maximum Brunt-Väisälä frequency (MaxStability, cycles $\mathrm{h}^{-1}$ ) and depth at maximum Brunt-Väisälä frequency (Mixed Layer, m). Brunt-Väisälä frequency was calculated using density data $\left(\mathrm{kg} \mathrm{m}^{-3}\right)$. PCA was applied based on the correlation matrix and on the variance-covariance matrix of $\log (\mathrm{x}+1)$ transformed abundances of fish larvae using Past 3.11 (Hammer et al. 2001). 
Figure 1. Spatial distribution of the bio-oceanographic cruise carried out during October 2014. Physical and biological data were collected in Golfo de Penas (GP) and along Baker (B), Fallos (F), Messier (M) and Wide (W) channels, south Chilean Patagonia / Distribución especial del crucero bio-oceanográfico llevado a cabo durante octubre 2014, donde se recolectaron datos físicos y biológicos en el Golfo de Penas (GP), y a lo largo de los canales Baker (B), Fallos (F), Messier (M) y Wide (W), Patagonia sur chilena

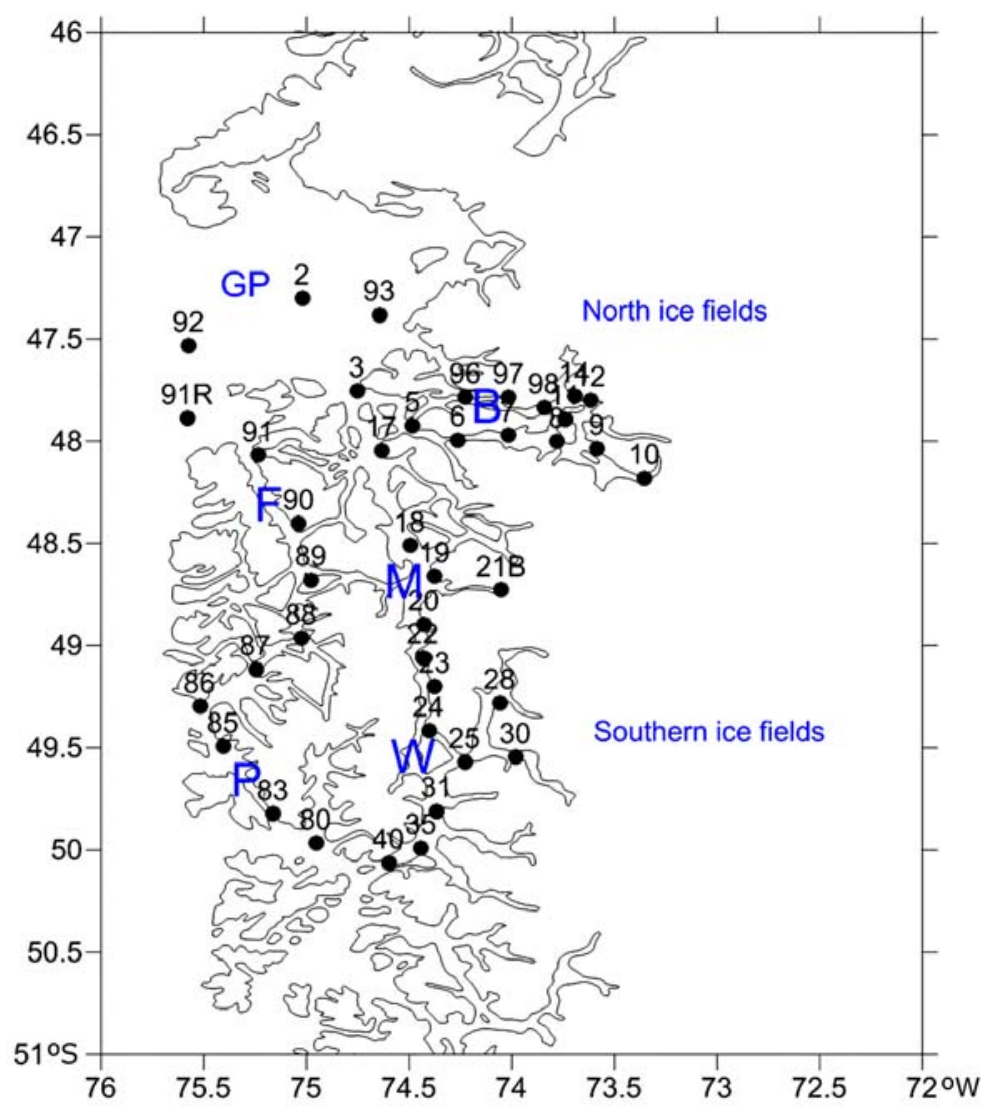

Comparison of hydrographic conditions as well as ichthyoplankton composition among areas (GP, BC, MWC and FLPC) was carried out with one-way PERMANOVA, using Bray-Curtis similarity index and 9999 permutations. Bonferroni-corrected $P$ values were used for post-hoc pairwise comparisons.

Partial least squares (PLS) regression is a method for exploring patterns of covariation between two blocks of variables. It can be used to analyze the relationship between form and function (Zelditch et al. 2012). In this case, PLS is useful for discriminating between groups when the number of variables exceeds the number of specimens. Two blocks of data, one of oceanographic data (Block 1) and the other of ichthyoplankton abundance (Block 2) were compared with PLS based on a correlation matrix, using Past 3.11, to determine coupling or uncoupling of the environmental forcing with the ichthyoplankton abundance throughout South Patagonia during October 2014.

\section{RESUlts}

\section{Physical settings And multivariate analysis}

Vertical profiles of physical conditions during the sampling period can be observed in Figures 2 and 3 . The section along GP and FLPC showed a well-mixed water column in terms of temperature and dissolved oxygen (Fig. 2), and with a slight decrease in temperature in the first $50 \mathrm{~m}$ depth from north to south. Salinity and density were stratified, with a steep vertical gradient at 20-25 m depth. Turbidity showed a maximum in GP (>1 NTU) and smaller values ( $<0.2$ NTU) along FLPC (Fig. 2).

The vertical section along the BC shows a clear effect of freshwater discharge from Baker and Pascua rivers (Fig. 3). There is a reduced salinity plume $(<14)$ near the surface (10 $\mathrm{m}$ depth) and a low subsurface sea water temperature $\left(<8^{\circ} \mathrm{C}\right)$; both parameters directly influence sea density, which displays strong vertical and 

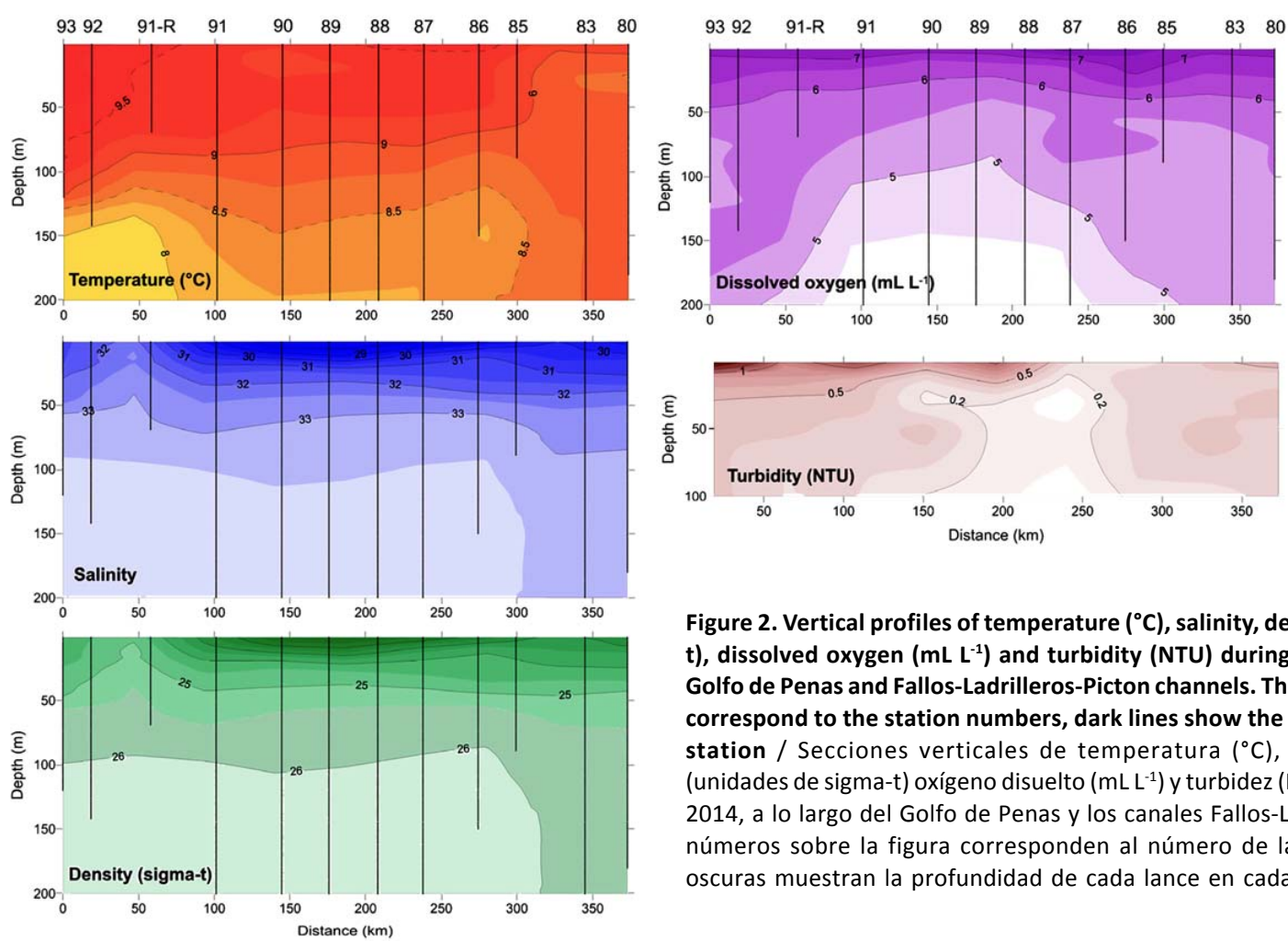

Figure 2. Vertical profiles of temperature $\left({ }^{\circ} \mathrm{C}\right.$ ), salinity, density (units of sigmat), dissolved oxygen ( $\mathrm{mL} \mathrm{L}^{-1}$ ) and turbidity (NTU) during October 2014 along Golfo de Penas and Fallos-Ladrilleros-Picton channels. The numbers on the top correspond to the station numbers, dark lines show the depth of cast at each station / Secciones verticales de temperatura $\left({ }^{\circ} \mathrm{C}\right)$, salinidad, densidad (unidades de sigma-t) oxígeno disuelto $\left(\mathrm{mL} \mathrm{L}^{-1}\right)$ y turbidez (NTU) durante octubre 2014, a lo largo del Golfo de Penas y los canales Fallos-Ladrilleros-Picton. Los números sobre la figura corresponden al número de la estación, las líneas oscuras muestran la profundidad de cada lance en cada estación
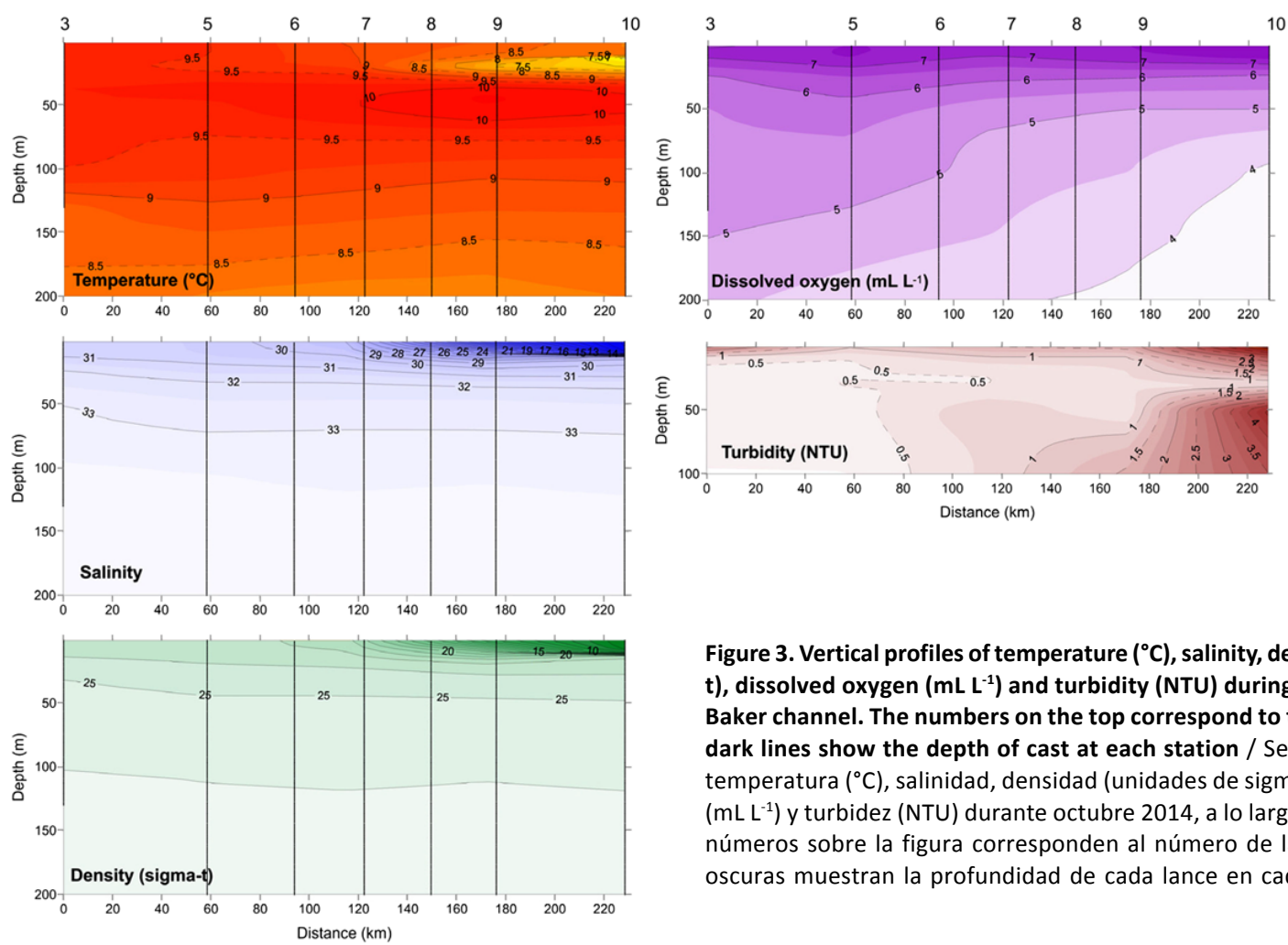

Figure 3. Vertical profiles of temperature $\left({ }^{\circ} \mathrm{C}\right.$ ), salinity, density (units of sigmat), dissolved oxygen ( $\mathrm{mL} \mathrm{L}^{-1}$ ) and turbidity (NTU) during October 2014 along Baker channel. The numbers on the top correspond to the station numbers, dark lines show the depth of cast at each station / Secciones verticales de temperatura $\left({ }^{\circ} \mathrm{C}\right)$, salinidad, densidad (unidades de sigma-t) oxígeno disuelto ( $\mathrm{mL} \mathrm{L}^{-1}$ ) y turbidez (NTU) durante octubre 2014, a lo largo del canal Baker. Los números sobre la figura corresponden al número de la estación, las líneas oscuras muestran la profundidad de cada lance en cada estación 
horizontal gradients along BC. The spatial structure of the physical conditions was also related to turbidity along the channel. In the area influenced by freshwater input, turbidity displayed high values (1-4 NTU) from $20 \mathrm{~m}$ depth to surface and deeper than $40 \mathrm{~m}$, with minimum values just below the pycnocline (Fig. 3). Finally, the water column along BC was well oxygenated $\left(>4 \mathrm{ml} \mathrm{L}^{-1}\right.$, Fig. 3).

The PCA indicated that the Principal Component 1 explained $62.7 \%$ of the variance, PCA 2 corresponds to $17.0 \%$ and PCA 3 explained $11.8 \%$ of the total variance (Fig. 4A, B). PCA 1 was positively related to SSS (factor loading, $\mathrm{fl}=0.923)$ and SSD ( $\mathrm{fl}=0.912$ ), and negatively related to the maximum stability ( $\mathrm{fl}=-0.855)$. PCA 2 was positively related to SST ( $\mathrm{fl}=0.614)$ and PCA 3 was positively related to the depth of the mixed layer $(\mathrm{fl}=$ 0.589) (Fig. 4). Therefore, according to PCA, turbidity was not a relevant factor in the spatial heterogeneity of the basins.

\section{COMPOSITION AND SPATIAL DISTRIBUTION OF FISH LARVAE}

A total of 1424 fish larvae were collected, representing 21 families and 41 taxa. The dominant taxa were the mesopelagic lightfish Maurolicus parvipinnis (31\%), rockfish Sebastes oculatus (12\%), southern hake Merluccius australis (11\%), myctophid Lampanyctodes hectoris (10\%), bathylagid Bathylagichthys parini (8\%), and myctophid Symbolophorus evermanni (3\%) (Table 1).

Larval M. parvipinnis displayed a patchy distribution, with higher abundances (>50 ind. $1000 \mathrm{~m}^{-3}$ ) in GP and along Fallos and Messier channels; specimens of this species were scarcely found along BC (Fig. 5). Similarly, L. hectoris, such as all the myctophid larvae, were mostly distributed in areas with oceanic influence (Fig. 5). Only one taxon was found in BC with higher abundances in turbid waters, corresponding to Nototheniid larvae. Instead, larval M. australis, S. oculatus and B. parini

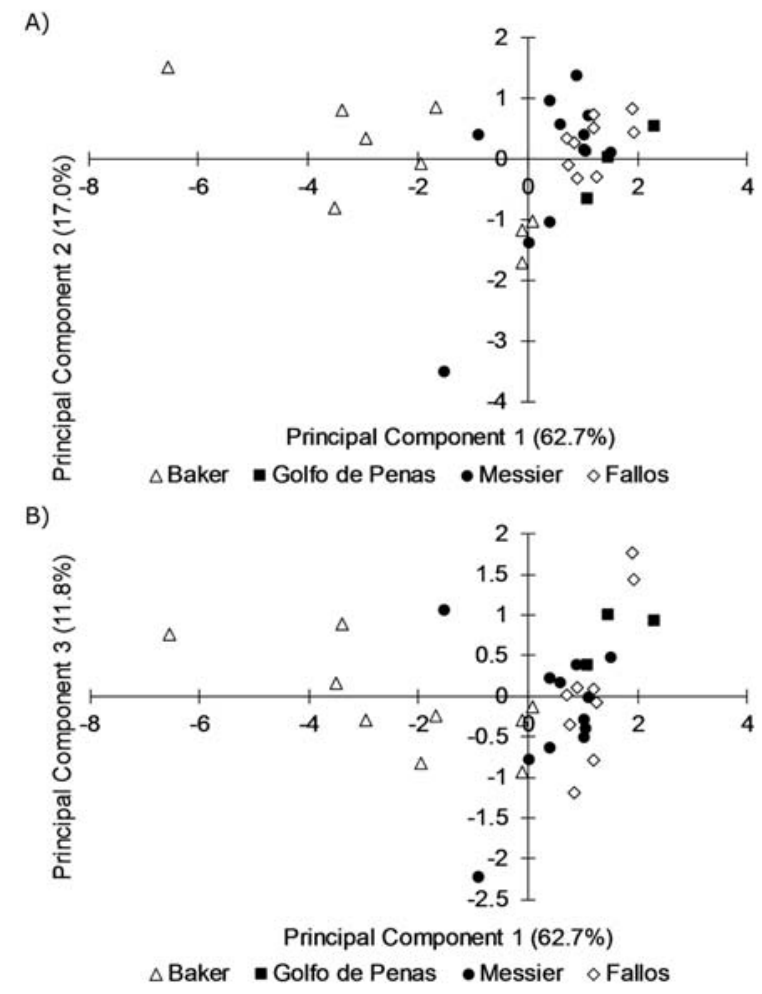

Figure 4. Principal component analysis (PCA) for oceanographic conditions during austral spring 2014 in Chilean Patagonia. A) PC1 vs. PC2, B) PC1 vs. PC3. Stations collected in Baker channel (white triangles), Messier-Wide channels (black dots), Fallos-Ladrilleros-Picton channels (white diamonds) and Golfo de Penas (black squares) / Análisis de Componentes Principales (PCA) para las condiciones oceanográficas durante la primavera 2014 en la Patagonia chilena. A) PC1 vs. PC2, B) PC1 vs. PC3. Las estaciones fueron recolectadas en el canal Baker (triángulos blancos), canales Messier-Wide (círculos negros), canales Fallos-Ladrilleros-Picton (diamantes blancos) y Golfo de Penas (cuadrados negros) 
Table 1. Ichthyoplankton composition and abundance (ind. $1000 \mathrm{~m}^{-3}$ ) collected in Chilean Patagonia during austral spring 2014 / Composición y abundancia (ind. $1000 \mathrm{~m}^{-3}$ ) del ictioplancton recolectado en la Patagonia chilena durante la primavera austral 2014

\begin{tabular}{|c|c|c|c|c|c|}
\hline Family & Species & Mean & SD & Median & Dominance (\%) \\
\hline \multirow[t]{3}{*}{ Clupeidae } & Ethmidium maculatum & 1.29 & & 1.29 & 0.04 \\
\hline & Sprattus fuegensis & 1.64 & 0.39 & 1.64 & 0.11 \\
\hline & Strangomera bentincki & 1.60 & 0.28 & 1.60 & 0.11 \\
\hline Engraulidae & Engraulis ringens & 1.55 & & 1.55 & 0.05 \\
\hline \multirow[t]{2}{*}{ Bathylagidae } & Bathylagichthys parini & 7.17 & 6.27 & 5.57 & 7.99 \\
\hline & Bathylagidae sp. 1 & 1.59 & & 1.59 & 0.06 \\
\hline \multirow[t]{2}{*}{ Gonostomatidae } & Cyclothone signata & 3.83 & & 3.83 & 0.13 \\
\hline & Cyclothone sp. & 2.46 & & 2.46 & 0.09 \\
\hline Sternoptychidae & Maurolicus parvipinnis & 25.74 & 43.60 & 7.47 & 31.36 \\
\hline Stomiidae & Stomias boa boa & 1.71 & & 1.71 & 0.06 \\
\hline \multirow[t]{12}{*}{ Myctophidae } & Benthosema sp. & 6.84 & & 6.84 & 0.24 \\
\hline & Gymnoscopelus sp. & 17.09 & & 17.09 & 0.59 \\
\hline & Lampanyctodes hectoris & 22.16 & 47.18 & 2.13 & 10.80 \\
\hline & Myctophum nitidulum & 2.60 & & 2.60 & 0.09 \\
\hline & Protomyctophum crockeri & 7.83 & 5.84 & 7.31 & 1.63 \\
\hline & Protomyctophum chilensis & 2.84 & 1.57 & 2.26 & 0.39 \\
\hline & Protomyctophum sp. 1 & 4.63 & 3.48 & 3.42 & 0.48 \\
\hline & Symbolophorus boops & 3.83 & & 3.83 & 0.13 \\
\hline & Symbolophorus evermanni & 14.28 & 10.05 & 14.59 & 2.98 \\
\hline & Symbolophorus sp. & 3.83 & & 3.83 & 0.13 \\
\hline & Myctophydae sp. 1 & 2.60 & & 2.60 & 0.09 \\
\hline & Myctophydae sp. 2 & 3.92 & 1.63 & 3.42 & 0.41 \\
\hline Gadidae & Micromesistius australis & 1.82 & 0.14 & 1.82 & 0.13 \\
\hline Merluccidae & Merluccius australis & 11.97 & 14.33 & 4.08 & 11.25 \\
\hline Macruronidae & Macruronus magellanicus & 6.85 & 7.73 & 5.19 & 2.14 \\
\hline \multirow[t]{2}{*}{ Macrouridae } & Macrouridae sp. 1 & 8.99 & 16.68 & 3.63 & 3.75 \\
\hline & Macrouridae sp. 2 & 1.80 & 0.11 & 1.76 & 0.19 \\
\hline \multirow[t]{2}{*}{ Ophidiidae } & Genypterus sp. 1 & 1.91 & & 1.91 & 0.07 \\
\hline & Genypterus sp. 2 & 1.95 & 0.63 & 1.91 & 0.34 \\
\hline Bythitidae & Cataetyx messieri & 2.12 & 0.87 & 1.66 & 0.96 \\
\hline Agonidae & Agonopsis chiloensis & 1.80 & & 1.80 & 0.06 \\
\hline Sebastidae & Sebastes oculatus & 8.65 & 7.67 & 6.46 & 12.04 \\
\hline Congiopodidae & Congiopodus peruvianus & 2.60 & & 2.60 & 0.09 \\
\hline Bovichthyidae & Bovichthys chilensis & 2.39 & 1.53 & 1.72 & 0.42 \\
\hline Tripterygiidae & Helcogrammoides cunninghami & 2.33 & 0.28 & 2.33 & 0.16 \\
\hline \multirow[t]{4}{*}{ Nototheniidae } & Nototheniidae sp. 1 & 3.47 & 3.63 & 1.81 & 1.81 \\
\hline & Nototheniidae sp. 2 & 15.52 & 22.25 & 2.59 & 3.24 \\
\hline & Nototheniidae sp. 3 & 1.82 & 0.14 & 1.82 & 0.13 \\
\hline & Nototheniidae sp. 4 & 2.98 & 1.20 & 2.98 & 0.21 \\
\hline Centrolophidae & Seriolella punctata & 1.77 & 0.50 & 1.71 & 0.31 \\
\hline Paralichthyidae & Thysanopsetta naresi & 1.55 & 0.05 & 1.55 & 0.11 \\
\hline Yolk-sac larvae & & 14.73 & & 14.73 & 0.51 \\
\hline Unidentified larvae & & 5.17 & 3.52 & 5.74 & 1.26 \\
\hline
\end{tabular}



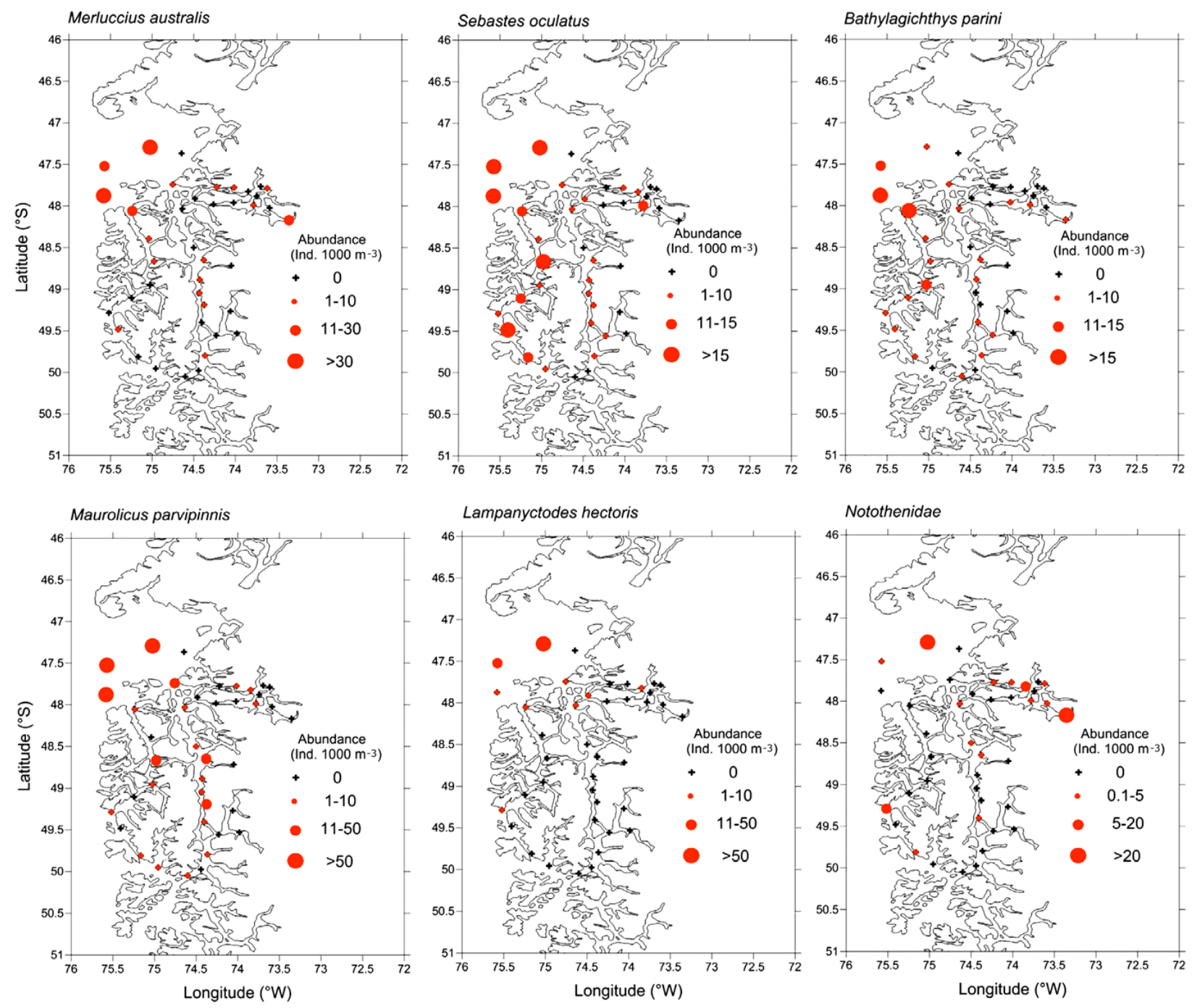

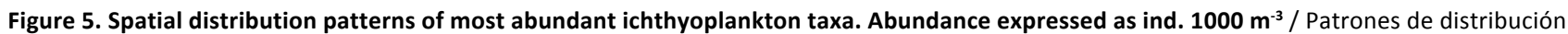
especial de taxa más abundantes del ictioplancton. Abundancia expresada en ind. $1000 \mathrm{~m}^{-3}$

were observed throughout the sampled area, with reduced abundances (10-30 ind. $1000 \mathrm{~m}^{-3}$ ) (Fig. 5).

The PCA of the most abundant ( $>1 \%$ ) log-transformed taxa indicated that PCA 1 explained $49.7 \%$ of the variance, while PCA 2 explained $13.1 \%$ of the total variance (Fig. 6). PCA 1 indicated a clear difference in the composition and abundance of fish larvae between fjords and channels from south Patagonia and those collected in oceanic waters from Golfo de Penas (Fig. 6). The variability in this axis was positively related to abundance of larval $M$. parvipinnis (factor loading $=0.579$ ) and larval M. australis ( $\mathrm{fl}=0.448$ ). PCA 2 showed a gradient in the ichthyoplankton assemblages from Fallos to
Messier to Baker Channels (Fig. 6); this axis was positively related to larval $S$. oculatus $(\mathrm{fl}=0.538)$ and negatively related to larval $M$. parvipinnis $(\mathrm{fl}=-0.411)$.

\section{COMPARISON OF ICHTHYOPLANKTON AT SPATIAL MESOSCALE}

One-way PERMANOVA detected significant differences in the composition and abundance of fish larvae throughout the studied area (pseudo- $F=16.03, P=0.0001$ ). Post-hoc tests established that all areas were significantly different (Bonferroni-corrected $P<0.0012$ ). Therefore, ichthyoplankton was structured at microbasin scale. 


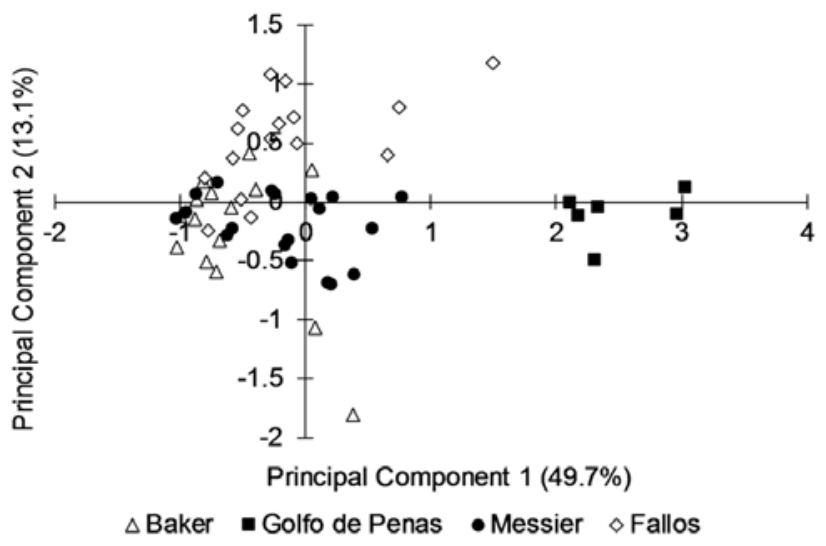

Figure 6. Principal Component Analysis for ichthyoplankton abundance during austral spring 2014 in Chilean Patagonia. Stations collected in Baker channel (white triangles), Messier-Wide channels (black dots), Fallos-Ladrilleros-Picton channels (white diamonds) and Golfo de Penas (black squares) / Análisis de Componentes Principales para la abundancia del ictioplancton durante la primavera 2014 en la Patagonia chilena. Las estaciones fueron recolectadas en el canal Baker (triángulos blancos), canales Messier-Wide (círculos negros), canales Fallos-Ladrilleros-Picton (diamantes blancos) y Golfo de Penas (cuadrados negros)

RELATIONSHIPS BETWEEN OCEANOGRAPHIC FEATURES AND LARVAL FISH ASSEMBLAGES

Partial least square analysis indicated that there was high and significant correlation (Pearson $r=0.695$, $P<<0.001$ ) between physical (block 1) and biological (block 2) matrices. The first axis explained 87.2\% showing a high covariance between both blocks (Fig. 7). Axis 1 of Block 1 was positively correlated with maximum stability $(r=0.52)$ and negatively correlated to surface salinity $(r=-0.422)$; turbidity was weakly correlated $(r=$ $0.26)$. Axis 1 of Block 2 was positively correlated to larval nototheniidae $(\mathrm{r}=0.422)$ and negatively to larval $S$. oculatus ( $r=-0.507)$. Therefore, in areas with high vertical stability caused by freshwater runoff, large abundance of nototheniid larvae occurred as well as low abundance of larval rockfish Sebastes.

\section{Discussion}

Hydrographic conditions and larval fish composition along south Patagonia showed high and significant variability among basins, sustaining the microbasin hypothesis (Antezana 1999). This suggests the effect of bathymetry on hydrographic discontinuities and the zooplankton composition in the Periantarctic Magellan

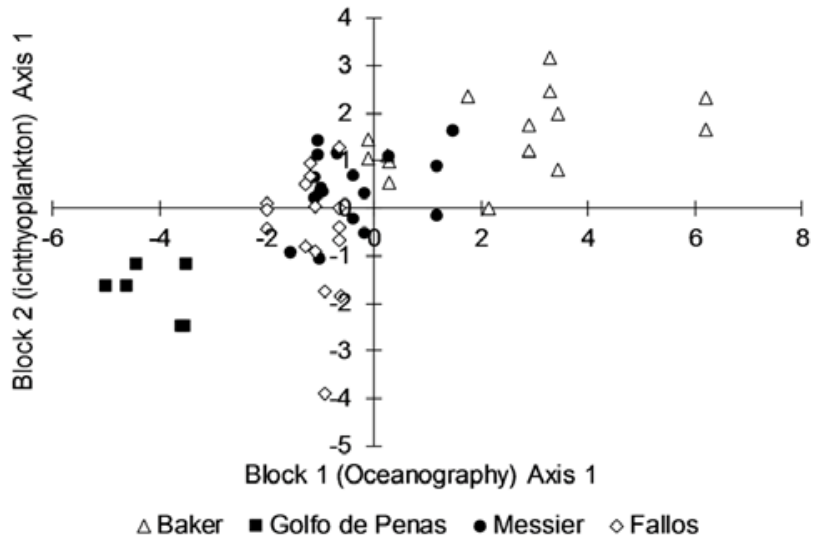

Figure 7. Partial Least Square (PLS) analysis for covariance between oceanographic conditions (Block 1) and ichthyoplankton composition (Block 2) during austral spring 2014 in Chilean Patagonia. Stations collected in Baker channel (white triangles), Messier-Wide channels (black dots), Fallos-Ladrilleros-Picton channels (white diamonds) and Golfo de Penas (black squares) / Análisis de Cuadrados Parciales Mínimos (PLS) para estimar la covarianza entre las condiciones oceanográficas (Bloque 1) y la composición del ictioplancton (Bloque 2) durante la primavera 2014 en la Patagonia chilena. Las estaciones fueron recolectadas en el canal Baker (triángulos blancos), canales Messier-Wide (círculos negros), canales Fallos-Ladrilleros-Picton (diamantes blancos) y Golfo de Penas (cuadrados negros)

Strait. Therefore, the microbasins can be also found in other locations along Chilean Patagonia, as suggested by recent studies (Lara et al. 2016).

The microbasins, channels and fjords, were environmentally influenced by salinity and density gradients rather than turbidity. Contrary to the proposed hypothesis, larval fish assemblages were not influenced by turbidity, at least at spatial scales of dozen to hundreds of meters.

The strongest signal of physical forcing was caused by the freshwater inputs from Baker and Pascua rivers. This stress was evident in the density horizontal gradients as well as turbidity gradients along Baker channel. During the season of maximum discharge, inshore transport of nauplii and offshore (to open ocean) advection of barnacle cyprids and squat lobster zoeae occurs (Meerhoff et al. 2015). Nonetheless, the important influence of freshwater discharge in the water column structure, austral spring is a period of lower sediment transport and higher primary productivity in the region (Meerhoff et al. 2013). This evidence suggest that this environment is highly dynamic at different temporal scales. Our results, therefore, represent a snapshot of the physical and biological conditions 
during October 2014, and it is part of other temporal signals, such as seasonal or interannual scales.

During October 2014, few individuals and taxa were able to use the greatly perturbed environment of Baker Channel as nursery zones. Among them, there were bathylagids, hakes and nototheniids larvae. Larval nototheniids, such as Patagonothen tessellatta are capable to ingest food prey during day and night hours (Salas-Berrios et al. 2013). This suggests that larval nototheniids could successfully ingest prey at low light intensities with turbid water parcels along Baker Channel. The bathylagid Bathylagichthys parini also utilize this habitat as nursery grounds from larval to juvenile stages (Uribe \& Balbontín 2005, Landaeta et al. 2011a), similar to southern hake tactics along Chilean Patagonia (Bustos et al. 2007, 2015). This spatial pattern seems to be ubiquitous throughout the Chilean Patagonia region (Bustos et al. 2008, 2011).

In open ocean areas, specifically in Golfo de Penas, larval fish assemblages were composed mainly by myctophid species, and particularly by Lampanyctodes hectoris. This is a pseudoceanic species, is confined to waters of the continental shelf and slope around Southern Africa, New Zealand and Chile (Florence et al. 2002). Spawning occurs in the shelf break zone (Prosch 1991) and larval L. hectoris is found mostly in offshore waters (Ahlstrom et al. 1976). Another important genus found in the GP was Symbolophorus; larvae of this genus can be found in warmer, offshore waters, and can be found in nearshore waters (Olivar \& Beckley 1994). Symbolophorus larvae are diel feeders, predating mainly on copepod eggs, nauplii and copepodites (Sassa 2010). Myctophid larvae, in contrast to majority of fish larvae of this region, has an enhanced sensitivity due to their pure rod-like retina, an adaptation for foraging at low light intensities (Sabatés et al. 2003). Therefore, high turbidity in channels and fjords of southern Chile is not a restriction for the intrusion of myctophid larvae to inner seas. Lower sea temperatures may prevent the intrusion of myctophid larvae; for example, no myctophid larvae has been collected in subarctic waters (Sassa et al. 2004), and therefore, a similar pattern may be occurring in the South Pacific Ocean. Previous studies in the area have also noticed the absence of myctophid larvae in the inner waters of the Chilean Patagonia (Bustos et al. 2008b, 2011). Absence of preferred prey may also prevent the selection of the area as nursery ground for myctophids (Swalethorp et al. 2015).
Partial least square results confirmed the pattern detected by PCA in the ichthyoplankton from Chilean Patagonia during austral spring 2014. Specifically, it detected a negative relationship between abundance of larval rockfish Sebastes oculatus and maximum stability. Recent studies in northern Patagonia have shown high phenotypic plasticity in terms of growth and trophic preferences of this rockfish species, enabling them to inhabit this highly perturbed ecosystem (Landaeta et al. 2015a, b).

Freshwater runoff was the main environmental forcing which affected the inner portion of fjords causing horizontal and vertical density gradients that ultimately influenced the two different larval fish assemblages, the first from channels and fjords, and the second from oceanic waters. No significant effect of turbidity gradients on larval fish assemblages was evident during spring at spatial scales of dozen to hundreds of kilometers, implying that we reject the hypothesis of the relevance of turbidity in the structuring of the ichthyoplankton taxocenosis. Nonetheless, the influence of turbidity in the feeding and predation of fish larvae cannot be ruled out.

\section{ACKNOWLedgMenTs}

This work is dedicated to the loving memory of Dr. Roberto Meléndez, and the discussion with MFL about the identity of Nansenia groenlandica/Bathylagichthys parini pair in the gut contents of southern hake. We appreciate the field work and cooperation of Ms. Viviana Ríos (Universidad de Valparaíso) and all the crew of RV 'Cabo de Hornos'. Jorge E. Contreras and Viviana Ríos helped in the separation of the ichthyoplankton. Comments and suggestions of Dr. Estrella Malca and Dr. María Teresa González improved an early version of the manuscript. This research was funded by Comité Oceanográfico Nacional (CONA) Grant C20F 14-09 to MFL and CAB.

\section{LITERATURE CITED}

Ahlstrom EH, HG Moser \& MJ O’Toole. 1976. Development and distribution of larvae and early juveniles of the commercial lanternfish, Lampanyctodes hectoris (Günther), off the west coast of southern Africa with a discussion of phylogenetic relationships of the genus. Bulletin of the Southern California Academy of Science 75: 138-152.

Aiken CM. 2012. Seasonal thermal structure and exchange in Baker Channel, Chile. Dynamics of the Atmosphere and Oceans 58: 1-19. 
Antezana T. 1999. Hydrographic features of Magellan and Fuegian Inland passages and adjacent Subantarctic waters. Scientia Marina 63(Suppl. 1): 23-34.

Balbontín F, F Uribe, R Bernal \& M Braun. 2004. Descriptions of larvae of Merluccius australis, Macruronus magellanicus, and observations on a larva of Micromesistius australis from southern Chile (Pisces: Gadiformes). New Zealand Journal of Marine and Freshwater Research 38: 609-619.

Boehlert GW \& JB Morgan. 1985. Turbidity enhances feeding abilities of larval Pacific herring, Clupea harengus pallasi. Hydrobiologia 123: 161-170.

Bustos CA, F Balbontín \& MF Landaeta. 2007. Spawning of the southern hake Merluccius australis (Pisces: Merluccidae) in Chilean fjords. Fisheries Research 83: 2332.

Bustos CA, MF Landaeta \& F Balbontín. 2008a. Spawning and early nursery areas of anchoveta Engraulis ringens Jenyns, 1842 in fjords of southern Chile. Revista de Biología Marina y Oceanografía 43(2): 381-389.

Bustos CA, MF Landaeta \& F Balbontín. 2008b. Efectos ambientales sobre la variabilidad espacial del ictioplancton de Chile austral durante noviembre de 2005. Revista Chilena de Historia Natural 81: 205-219.

Bustos CA, MF Landaeta \& F Balbontín. 2011. Ichthyoplankton spatial distribution and its relation with water column stratification in fjords of southern Chile (46 $48^{\prime}$ 5009’S) in austral spring 1996 and 2008. Continental Shelf Research 31: 293-303.

Bustos CA, MF Landaeta, P Palacios-Fuentes, N JahnsenGuzmán \& F Balbontín. 2015. Comparing early life traits of hakes from Chilean Patagonian fjords inferred by otolith microstructure analysis. Fisheries Research 164: 35-44.

Contreras T, LR Castro, S Montecinos, HE González, S Soto, MI Muñoz \& S Palma. 2014. Environmental conditions, early life stages distributions and larval feeding of Patagonian sprat Sprattus fuegensis and common sardine Strangomera bentincki in fjords and channels of northern Chilean Patagonia. Progress in Oceanography 129: 136-148.

Florence WK, PA Hulley, BA Stewart \& MJ Gibbons. 2002. Genetic and morphological variation of the lanternfish Lampanyctodes hectoris (Myctophiformes: Myctophidae) off southern Africa. South African Journal of Marine Science 24: 193-203.

Grecay PA \& TE Targett. 1996. Effects of turbidity, light level and prey concentration on feeding of juvenile weakfish Cynoscion regalis. Marine Ecology Progress Series 131: 11-16.

Hammer Ø, DAT Harper \& PD Ryan. 2001. PAST: Paleontological statistics software package for education and data analysis. Palaeontologia Electronica 4(1): 9.

Landaeta MF, F Balbontín \& GA Herrera. 2008. Larval development of the Patagonian brotula Cataetyx messieri
(Pisces, Bythitidae) from fjords of southern Chile. Journal of Fish Biology 73: 302-310.

Landaeta MF, N Suárez-Donoso, CA Bustos \& F Balbontín. 2011a. Feeding habits of larval Maurolicus parvipinnis (Pisces: Sternoptychidae) in Patagonian fjords. Journal of Plankton Research 33(12): 1813-1824.

Landaeta MF, J Contreras \& CA Bustos. 2011b. Fiordos de Chile: potencial zona de crianza de Bathylagichthys parini (Pisces: Osmeriformes: Bathylagidae). Revista de Biología Marina y Oceanografía 46: 67-71.

Landaeta MF, G López, N Suárez-Donoso, CA Bustos \& F Balbontín. 2012. Larval fish distribution, growth and feeding in Patagonian fjords: potential effects of freshwater discharge. Environmental Biology of Fishes 93: 73-87. < doi: 10.1007/s10641-011-9891-2>

Landaeta MF, RA Martínez, CA Bustos \& LR Castro. 2013. Distribution of microplankton and fish larvae related to sharp clines in a Patagonian fjord. Revista de Biología Marina y Oceanografía 48: 401-407. <doi: 10.4067/S071819572013000200020>

Landaeta MF, CA Bustos, JE Contreras, F Salas-Berríos, P Palacios-Fuentes, M Alvarado-Niño, J Letelier \& F Balbontín. 2015a. Larval fish feeding ecology, growth and mortality from two basins with contrasting environmental conditions of an inner sea of northern Patagonia, Chile. Marine Environmental Research 106: 19-29.

Landaeta MF, JE Contreras, CA Bustos \& A Pérez-Matus. 2015b. Growth and condition of larval rockfish in a Patagonian fjord-type inlet: role of hydrographic conditions and food availability. Aquatic Ecology 49: 573-584.

Lara C, GS Saldías, FJ Tapia, JL Iriarte \& BR Broitman. 2016. Interannual variability in temporal patterns of chlorophyll-a and their potential influence on the supply of mussel larvae to inner waters in northern Patagonia (41$\left.44^{\circ} \mathrm{S}\right)$. Journal of Marine System 155: 11-18.

Meerhoff E, L Castro \& F Tapia. 2013. Influences of freshwater discharges and tides on the abundance and distribution of larval and juvenile Munida gregaria in the Baker river estuary, Chilean Patagonia. Continental Shelf Research 61/62: 1-11.

Meerhoff E, FJ Tapia \& LR Castro. 2014. Spatial structure of the meroplankton community along a Patagonian fjord The role of changing freshwater inputs. Progress in Oceanography 129: 125-135. <doi: 10.1016/j.pocean.2014. 05.015>

Meerhoff E, F J Tapia, M Sobarzo \& L Castro. 2015. Influence of estuarine and secondary circulation on crustacean larval fluxes: a case study from a Patagonian fjord. Journal of Plankton Research 37: 168-182. <doi: 10.1093/plankt/fbu106>

Olivar MR \& LE Beckley. 1994. Investigations on the occurrence of larvae of Symbolophorus species (Myctophidae) off southern Africa. South African Journal of Marine Science 14: 349-359. 
Prosch RM. 1991. Reproductive biology and spawning of the myctophid Lampanyctodes hectoris and the sternoptychid Maurolicus muelleri in the southern Benguela Ecosystem. South African Journal of Marine Science 10: 241-252.

Quiroga E, P Ortiz, D Gerdes, B Reid, S Villagran \& R Quiñones. 2012. Organic enrichment and structure of macrobenthic communities in the glacial Baker Fjord, Northern Patagonia, Chile. Journal of the Marine Biological Association of the United Kingdom 92(1): 73-83.

Sabatés A, A Bozzano \& I Vallvey. 2003. Feeding pattern and the visual light environment in myctophid fish larvae. Journal of Fish Biology 63: 1476-1490.

Salas-Berríos F, J Valdés-Aguilera, MF Landaeta, CA Bustos, A Pérez-Vargas \& F Balbontín. 2013. Feeding habits and diet overlap of marine fish larvae from the periAntarctic Magellan region. Polar Biology 36: 1401-1414. < doi: 10.1007/s00300-013-1359-8>

Sassa C. 2010. Feeding ecology of Symbolophorus californiensis larvae (Teleostei: Myctophidae) in the southern transition region of the western North Pacific. Journal of the Marine Biological Association of the United Kingdom 90: 1249-1256.

Sassa C, K Kawaguchi, Y Oozeki, H Kubota \& H Sugisaki. 2004. Distribution patterns of larval myctophid fishes in the transition region of the western North Pacific. Marine Biology 144: 417-428.
Swalethorp R, E Malanski, MD Agersted, TG Nielsen \& P Munk. 2015. Structuring of zooplankton and fish larvae assemblages in a freshwater-influenced Greenlandic fjord: influence by hydrography and prey availability. Journal of Plankton Research 37(1): 102-119.

Uribe F \& F Balbontín. 2005. First description of larvae of Bathylagichthys parini (Pisces, Bathylagidae) from the southeastern Pacific. Bulletin of Marine Science 77: 201207.

Utne-Palm AC. 2002. Visual feeding of fish in a turbid environment: physical and behavioural aspects. Marine and Freshwater Behaviour and Physiology 35: 111-128.

Vargas CA, RA Martinez, V San Martin, M Aguayo, N Silva \& R Torres. 2011. Allochthonous subsidies of organic matter across a lake-river-fjord landscape in the Chilean Patagonia: implications for marine zooplankton in inner fjord areas. Continental Shelf Research 31: 187-201.

Zenteno JI, CA Bustos \& MF Landaeta. 2014. Larval growth, condition and fluctuating asymmetry in the otoliths of a mesopelagic fish in an area influenced by a large Patagonian glacier. Marine Biology Research 10: 504-514. <doi: 10.1080/17451000.2013.831176>

Received 30 May 2016 and accepted 23 July 2017

Associated Editor: María T. González 